\section{Radon mapping in Croatia and its relation to geology}

The Mining-Geology-Petroleum Engineering Bulletin UDC: 910.27

DOI: 10.17794/rgn.2018.3.1

Review scientific paper

\author{
Ana Mostečak ${ }^{1}$; Dario Perković́; Frankica Kapor³ ${ }^{3}$ Želimir Veinović $^{4}$ \\ ${ }^{1}$ University of Zagreb, Faculty of Mining, Geology and Petroleum Engineering, Pierottijeva 6, 10000 Zagreb, Croatia \\ ${ }^{2}$ University of Zagreb, Faculty of Mining, Geology and Petroleum Engineering, Pierottijeva 6, 10000 Zagreb, Croatia \\ ${ }^{3}$ University of Zagreb, Faculty of Mining, Geology and Petroleum Engineering, Pierottijeva 6, 10000 Zagreb, Croatia \\ ${ }^{4}$ University of Zagreb, Faculty of Mining, Geology and Petroleum Engineering, Pierottijeva 6, 10000 Zagreb, Croatia
}

\begin{abstract}
Radon is known as the main contributor to natural background radiation exposure and the mapping of different radon phenomenon presents an important task in both a scientific and regulatory context. Considering the aspect of radon effects on health, identification of areas with elevated radon levels is a crucial step in radon monitoring and the prevention of adverse effects on the population and the environment. Different needs regarding the monitoring of the environmental radioactivity levels in Europe led to initiatives such as the development of the European Atlas of Natural Radiation (EANR). To present different methods of radon mapping, the European Indoor Radon Map and European Geogenic Radon Map projects are described briefly. The aim of this paper is to present the mapping of different aspects of radon (indoor and geogenic) and its importance in data visualization and information dissemination. The practical experiences worldwide provide context for future activities of radon mapping in Croatia. Existing Croatian initiatives in the field of radon risk research are mostly related to the investigations of indoor radon concentrations and identification of radon prone areas through one national study and several focused studies. A comparison of indoor radon levels in Croatia and several geological parameters identified new areas appropriate for future research that could lead towards a geogenic map of radon potential in Croatia.
\end{abstract}

Keywords:

radon mapping, geology, Croatia, GIS, natural radioactivity.

\section{Introduction}

One of the main concerns of environmental protection is the issue of protection of humans and the environment from harmful levels of exposure and mitigation of harmful effects arising from the exposure to hazards. Even though the exposure to ionizing radiation from natural sources is considered as "a continuing and inescapable feature of life on earth" (UNSCEAR, 2000), radon is known as the main contributor to natural background radiation exposure. Besides radon's importance in radiation prevention and protection, it is also the most studied geochemical precursor in earthquake prediction research.

Radon is an inert, alpha-emitting gas that is generated from the uranium series i.e. one of the four known natural decay series that occur naturally, also known as primordial radionuclides. It has no stable isotopes and they all differ in their half-lives. Out of 34 known isotopes of radon, only three originate from the decay of primordial radionuclides and two are present in the environment in

Corresponding author: Ana Mostečak

ana.mostecak@gmail.com significant amounts. The most common isotope, usually known as radon, is radon-222 $\left({ }^{222} \mathrm{Rn}\right)$, which is a member of the ${ }^{238} \mathrm{U}$ decay series with a half-life of 3.82 days. The other two isotopes are radon-220 $\left({ }^{220} \mathrm{Rn}\right)$, known as thoron, with a half-life of $55.6 \mathrm{~s}$ and radon-219 $\left({ }^{219} \mathrm{Rn}\right)$, known as actinon, with a half-life of $3.96 \mathrm{~s}$. As a colourless, tasteless, and odourless gas, radon is difficult to detect even in high concentrations. Figure 1 shows the complete ${ }^{238} \mathrm{U}$ decay chain.

The source and the amounts of radon present in the environment are natural but are also influenced by anthropogenic activities. In rocks and soils, radon is usually locked inside the mineral matrix but is released to the interstitial space between grains when the radium decays (UNSCEAR, 2000). The radon emanation factor i.e. the fraction of all radon atoms that escape the grains is determined by several characteristics, like the radium atom content of the soil and its distance from the parent radium atom, etc. (Tracy, 2010; Sykora, 2010). Before their release into the atmosphere or their decay, radon atoms are transported by diffusion and advection (UNSCEAR, 2000). According to Gregorič et al. (2012), hydro-meteorological conditions govern the exhalation 


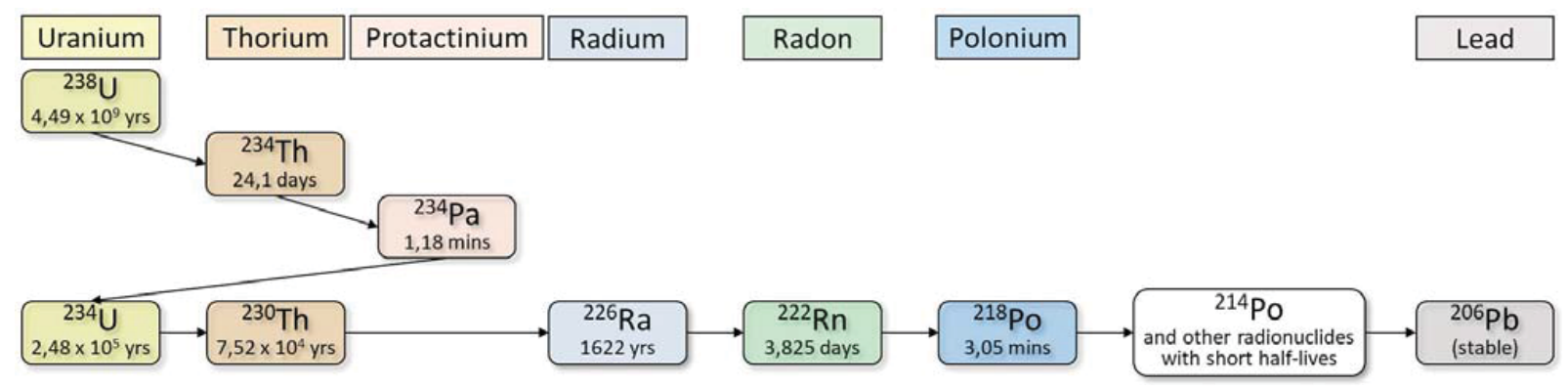

Figure 1: Uranium decay chain

of radon, while transport in the earth is related to the geophysical and geochemical parameters. According to Etiope and Martinelli (2002) in different geological scenarios the transport and redistribution of trace gases $(\mathrm{Rn}, \mathrm{He})$ is often determined by the carrier gases $\left(\mathrm{CO}_{2}\right.$, $\mathrm{CH}_{4}$ ) which can even be considered as a controlling factor in the transport of rare gases (Etiope and Martinelli, 2002). Radon is also dissolved in water and tends to remain dissolved in water and contribute to the concentration of the levels present in the groundwater (Tracy, 2010). Radon concentrations in the soil are responsible for diffusion to the atmosphere, which is dictated by soil properties, especially soil moisture (UNSCEAR, 2000) and the pressure gradient. Radon concentration close to the surface, i.e. a few meters below the ground, provides information in determining radon exhalation rate in the atmosphere (UNSCEAR, 2000). There are three main factors influencing indoor radon levels: uranium and radium content in the soil/rock, environmental conditions that affect radon's transport from the soil, and meteorological parameters that affect the exhalation of radon from the soil to the atmosphere (Ciotolli et al., 2017).

The Harvard Center for Cancer Prevention states that ionizing radiation is the most studied environmental carcinogen, with the exception of tobacco smoke (Wakeford, 2004). According to the UNSCEAR report from 2000, radon health risks related to underground mine exposure were well known, but research on the health effects arising from the indoor radon exposure only started in the 1970s (UNSCEAR, 2000). For humans, the main exposure pathway for radon is through inhalation. Since radon alone is not very active and is eliminated from the body, it's the inhalation of radon decay products $\left({ }^{218} \mathrm{Po},{ }^{214} \mathrm{Po},{ }^{214} \mathrm{~Pb},{ }^{214} \mathrm{Bi}\right)$ that poses the greatest health risk by disposition along the airways and irradiation of the bronchial tree and lungs (UNSCEAR, 2000). Besides smoking, exposure to radon progeny is considered one of the main contributors to the occurrence of lung cancer (ICRP, 1987; ICRP, 2010; WHO, 2009). Considering the aspect of radon effects on health, identification of areas with elevated radon levels presents a crucial step in radon monitoring and the prevention of adverse effects on the populations and the environment.

According to Dubois et al., map visualization of the occurrence of ${ }^{222} \mathrm{Rn}$ and its decay products "has been of major public, regulatory, and scientific interest for two to three decades" (Dubois et al., 2010). The Euratom Treaty requires the European Commission to "collect, validate and provide information about the levels of radioactivity in the environment" (De Cort et al., 2011). Several authors mention different needs regarding the monitoring of the environmental radioactivity levels present on the European legal, regulatory and scientific levels that led to the initiatives such as the development of the European Atlas of Natural Radiation (EANR) (Dubois, 2005; Gruber et al.; 2013; Tollefsen et al., 2014; Cinelli and Tollefsen, 2016). The EANR project was started by the Radioactivity Environmental Monitoring (ERM) group at the European Commission's Joint Research Centre (JRC), with the main objectives of introducing the concept of natural radioactivity to the general public, identifying the areas where natural radioactivity levels are elevated and providing reference materials and data to the scientific community (Gruber et al., 2013; Dubois et al., 2010). EANR should provide an overview of the different variables related to the sources of natural radioactivity and their geographic distribution in different stages, e.g. the generation stage and the stage of the actual phenomenon that causes concern (Gruber et al., 2013). The European Indoor Radon Map (EIRM) project has made significant progress and its outputs will be presented in the upcoming section. It was based on national indoor radon measurement initiatives across the Member States. The European Geogenic Radon Map (EGRM) presents a challenging task with the aim of mapping only what Earth itself delivers, i.e. the radon levels resulting from natural reasons, "irrespective of anthropogenic factors and temporally constant over a geological timescale" (Gruber et al., 2013). In this context, the radon phenomenon is termed as geogenic radon potential (GRP). A more detailed overview of the different aspects of geogenic radon mapping will be given in the next section. Besides the maps covering the indoor radon values and the geogenic radon potential, cosmic radiation, terrestrial gamma, and outdoor radon maps are also planned (De Cort et al., 2011). According to De Cort et al., the long-term overall goal of the EANR is to calculate the total dose caused by the natural radioactivity for a population by using different data and to present these values in a map (De Cort et al., 2011). 
The Article 103 of the EC Directive 2013/59/Euratom states that the "Member States shall identify areas where the radon concentration (as an annual average) in a significant number of buildings is expected to exceed the relevant national reference level" (EC, 2013). Additionally, the document states that the Member States should establish a radon action plan which should be submitted to the European Commission. The same requirement is mentioned by the IAEA (IAEA, 2012). Gruber et al. (2013) present a definition of the radon prone areas as proposed in the preparation of the new Euratom Basic Safety Standards Directive: "a geographic area or administrative region defined on the basis of surveys indicating that the percentage of dwellings expected to exceed the national reference level is significantly higher than in other parts of the country" (Gruber et al., 2013). The concept of radon prone areas is usually used in the geogenic radon potential mapping.

Given the information present herein, the necessity and significance of the identification and monitoring of different radon phenomenon, on both national and international levels with regard to various regulatory and scientific aspects, gives radon mapping a crucial role in the radiation protection of humans and the environment. The aim of this paper is to present the mapping of different aspects of radon (indoor and geogenic) and its importance in data visualization and information dissemination. Practical experiences worldwide provide context for future activities in radon mapping in Croatia and may be taken as the first step towards a geogenic map of radon potential in Croatia.

\section{Overview of radon mapping initiatives in the world}

There are two general approaches to the mapping of the radon phenomenon: the first one relies on the values of indoor radon levels to derive a radon risk map, where the second one combines the indoor radon data with the available geological data. While the values of indoor radon levels are usually used for determining areas at risk, as in the example of the EIRM project (Dubois, 2005), due to the complexity and demanding nature of data collection, different authors are developing radon potential maps through geologically based methods (Ielsch et al., 2010; Szabó et al., 2014; Kemski et al., 2001; 2009; Watson et al., 2017; Sainz Fernández et al., 2017; Ciotoli et al., 2017; Minda et al., 2009).

The first step in the preparation of the European Atlas of Natural Radioactivity was the mapping of indoor radon levels. European Indoor Radon Map was based on data provided by the EU Member States from their national radon surveys. JRC collected the data through a questionnaire in order to get an overview of the status of radon surveys and methodologies used in different countries (Dubois, 2005). Details are available in the full report (Dubois, 2005), but general conclusions were that no country used the same methodology. Overall, the estimated number of European dwellings where radon measurements were conducted was between 1.5 and 2 million, with the number of measurements being between 3 and 4 million due to the fact that measurements were sometimes done in several rooms in one dwelling, usually in bedrooms and living rooms. In this context, Tollefsen et al. (2014) mention a remark for future actions concerning the fact that there are people who do not live on the ground floor but on higher floors where radon levels are considered to be lower, which is especially true for cities. They stress the importance for surveys to refer to the aspect of population density and house occupation characteristics. Regarding the conduction of measurements, in the sampling density aspect, some countries used a population-weighted approach where others decided for a homogenous coverage of the territory (Tollefsen et al., 2014). Also, in defining local mean values, most of the countries used administrative borders, where some used a grid as a reference system and only a few relied on the interpolation or geostatistical techniques (Dubois, 2005). Measurements differ in the sampling time (from a few hours up to a year), selection of buildings types (public buildings, single or multifamily houses, etc.), but in most countries, they included soil-gas measurements. Additionally, the majority of countries used the EU recommended annual mean indoor concentrations as their reference level, which is $400 \mathrm{Bqm}^{-3}$ for existing buildings and $200 \mathrm{Bqm}^{-3}$ for new buildings (Dubois, 2005). In the context of data interpolation and the lack of spatial correlation, Ciotoli et al. (2017) mention a possibly misleading aspect of this approach (Ciotoli et al., 2017).

It is interesting to mention that according to Tollefsen et al., (2014), data from the indoor radon concentrations map in Europe are related to the "granitic areas of the Bohemian Massif, the Iberian Peninsula, the Massif Central, the Fennoscandian shield, Corsica, Cornwall and the Vosges Mountains, the crystalline rocks of the Central Alps, karst rocks of the Swiss Jura and the Dinarides, the black shales in North Estonia and in certain volcanic structures in central Italy." (Tollefsen et al., 2014).

Where EIRM uses the direct measurements of indoor radon concentrations for mapping, the use of geogenic radon potential concept is known as an indirect method (Cinelli and Tollefsen, 2016). The European Geogenic Radon Map relies on the geogenic radon potential as a spatial variable to be mapped. In developing the EGRM, the main challenges were related to the selection and collection of input variables and the identification of the multivariate method of defining the radon potential (De Cort et al., 2011). Variables selected to best target the final GRP variable consist of different geological and tectonic data (polygons and line data) and soil gas radon concentrations, geochemical concentrations in the soil and soil permeability, geophysical data, etc. (point data) 
(De Cort et al., 2011; Gruber et al., 2013). Another important factor in the project development is the availability and the accessibility of data. The European OneGeology Project provided the age and lithology data to be used as a basis for deriving the GRP. As mentioned by Ciotolli et al. in their work on mapping the GRP of the Lazio region in Italy, while the GRP concept is widely used in the radon risk mapping, a generally accepted approach has yet to be developed (Ciotoli et al., 2017). In quantifying the radon potential, there are two ways of deriving the GRP variable, a physics-driven approach (known as the continuous variable approach) and the radon index approach, also known as the multivariate classification approach or cross-tabulation (Gruber et al., 2013; De Cort et al., 2011). According to Gruber et al. (2013) the physics-driven approach is based on the quantity that best describes the processes that most contribute to the GRP, and this quantity is very well represented by the value known as "Neznal RP" due to its similarity to the proposition by Neznal et al. from 2004 (Gruber et al., 2013). The model for assessing radon potential from Neznal et al. (2004) is based on measurements of both soil gas radon concentrations and soil permeability, as seen in Equation 1 (Gruber et al., 2013, Szabó et al., 2014). RP should reflect the available radon from the ground, irrespective of the anthropogenic factors such as building type, etc. (Friedmann et al., 2017). A detailed overview of the inputs used in the Equation 1 for deriving the RP values is available in Gruber et al. (2013).

$$
R P=C /\left(-\log _{10} \log _{10} k-10\right)
$$

where:

$C$ - radon concentration in soil air $\left(\mathrm{kBqm}^{-3}\right)$

$k$ - soil permeability $\left(\mathrm{m}^{2}\right)$.

Radon index (RI) or the multivariate classification approach relies on scoring the input variable combinations, e.g. high soil Rn content and low permeability combined result in a score. All the scores are summed and then classified resulting in RI classes (low, medium, high) (De Cort et al., 2011; Gruber et al., 2013). This approach is very applicable for the European context given the diversity of input data. Some of the best practice experiences with the radon index method are available from Germany, France, the Czech Republic and the USA (Gruber et al., 2013) and were used for providing the default RP of the geological units (Tollefsen et al., 2014). The EGRM is based on the radon index derivation where the main challenge was to incorporate different sets of data, sometimes partial or differing in quality, into the GRP variable (De Cort et al., 2011).

Besides the method used in the EGRM, De Cort et al. (2011) mention other approaches that can be used in radon risk mapping: a probabilistic approach based on the statistical correlation of the observed data, an analytical approach defining the radon hazard index, a "posteriori" approach defining GRP as a normalized indoor concen- tration, and the exceedance probability of indoor concentration approach (De Cort et al., 2011). The input variables in the radon index approach are shown in Figure 2 (Cinelli and Tollefsen, 2016).

Another important aspect of radon risk mapping is the estimation of the target variable and its assignment to a spatial unit (either an administrative or a geological unit). The variables are estimated from the input data i.e. RP or index value. For estimation purposes, sometimes point data can be joined to one unit by the use of the mean value of all the points belonging to that unit, as in the development of the EIRM.

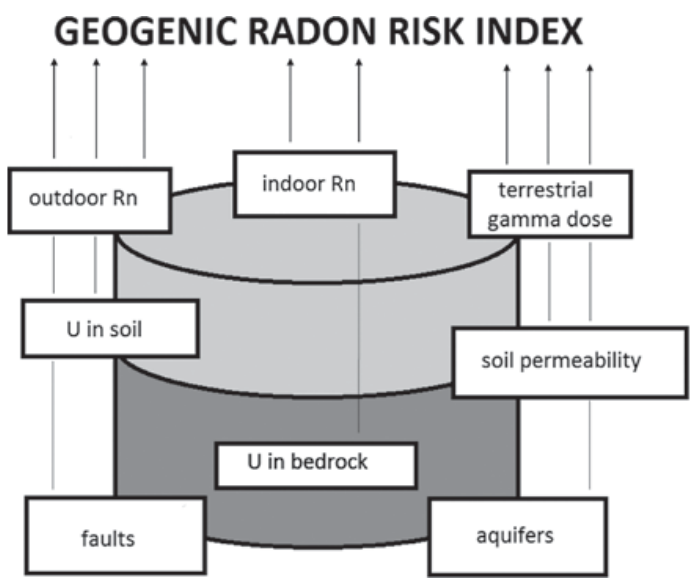

Figure 2: Input variables for Radon Index derivation (after Cinelli and Tollefsen, 2016)

Gruber et al. (2013) mention that for the estimation support, polygons are considered as most applicable to represent the geological units. Gruber et al. (2013) also list two main types of problems encountered during the development of the EGRM: heterogeneity and conceptual issues. Heterogeneity issues result from differences in the datasets gathered across the Member States, differences in the protocols used in the measurements or variables measured, geological classification used, etc., all of which first need to be harmonized in order to be used for mapping (Gruber et al., 2013). Conceptual issues are mainly related to geology. Since radon potential depends on the radon source term and migration properties, which are covered by the use of different geological units in the classification system, sometimes those units and categories fail to include all the geological details important for the GRP (Gruber et al., 2013).

According to Ciotolli et al. (2017), GRP is connected to the local geology and if properly defined it can be of use in determining radon prone areas, especially in the situations where the amounts and/or quality of the indoor radon data is not sufficient. Regarding the correlation of the data available from the measurements of indoor radon levels and geological data, several authors researched the correlation between these two sets of variables (Bossew et al., 2008; García-Talavera et al., 
2013; Friedmann et al., 2017). Work by Bossew et al. (2008) focuses on the deterministic prediction of regional RP based on the geological classes and stochastic modelling of RP in Austria. García-Talavera et al. (2013) presented a methodology for mapping RPA in Spain by using already available indoor radon measurements and surrogate information and combining it with data on natural $\gamma$-radiation. Friedmann et al. (2017) used indoor radon concentration measurements for dwellings in Upper Austria paired with data on radium in soil, the soil gas radon concentration, soil permeability, and the ambient dose equivalent rate, while paying attention to the geological units present. Besides the "Neznal RP" $\left(\mathrm{RP}_{\mathrm{N}}\right)$, the authors also calculated the "Austrian RP - radon concentration in a standard room" $\left(\mathrm{RP}_{\mathrm{A}}\right)$ with the aim of correlating different variables and checking the use of surrogate data instead of indoor radon measurements (Friedmann et al., 2017). The results of their study showed that while $\mathrm{RP}_{\mathrm{N}}$ correlates well with the soil gas radon concentrations, and $\mathrm{RP}_{\mathrm{A}}$ correlates well with the indoor radon concentrations, a correlation between the $\mathrm{RP}_{\mathrm{N}}$ and the $\mathrm{RP}_{\mathrm{A}}$ is found only when the soil gas radon concentration is approximately equal to $60 \mathrm{kBqm}^{-3}$ (Friedmann et al., 2017). The correlation between the indoor radon concentrations and radium in soil and soil gas radon concentration variables was not sufficient, where only summarization of different geological units lead to better correlation results (Friedmann et al., 2017). Concerning the radon risk classification, the authors conclude that even knowing the data on all the radon relevant variables except the indoor radon concentrations does not suffice to define the radon risk for a geological area, but can provide indications and be used as a quick method of getting a general view of which areas call for further measurements and investigation (Friedmann et al., 2017).

Chambers and Zielinski (2011) provide a good overview of residential radon levels and radon data availability around the world. Canada is considered a country where the first large national residential radon survey was done in the 1970s and 1980s. The authors also mention data from UNSCEAR related to the worldwide average values of indoor radon levels for 2000, where the unweighted average mean value worldwide was $46 \mathrm{Bqm}^{-3}$ and $39 \mathrm{Bqm}^{-3}$ population weighted (Chambers and Zielinski, 2011). In the worldwide context, different authors are working on radon risk mapping and carrying out different radon research projects. In their work, Ciotoli et al. (2016) used Geographical Weighted Regression (GWR) and geostatistics in order to produce a GRP map of the Lazio region in Italy, with an assumption that the radon risk of an area is only dependant on the environmental and geological parameters. For prediction of radon prone areas Bossew (2014) used GRP as a predictor and thresholds of indoor radon concentrations, but not by doing a transfer model from geogenic to indoor radon, but by optimizing the geological classification and grouping.
Some authors focused on the effects and influence of variables from construction, i.e. building factors. Borgoni et al. (2014) used data from several Lombardy municipalities (Italy) to research the effect that a range of building characteristics has on indoor concentrations, especially on different floor levels. The authors used hierarchical modelling. The results showed that windows and wall materials had a significant influence on indoor radon concentrations, while soil type and building type (attached or detached) did not have a significant effect. The most influential variable was the floor, with the basement and ground floor being more associated with elevated radon levels than the higher floor, but without a linear behaviour (Borgoni et al., 2014). Kemski et al. (2009) used indoor radon measurements from 10000 dwellings in order to examine the statistical relationship between building materials, house types and indoor radon concentrations. Hunter et al. (2009) examined house-specific factors based on the survey on radon concentrations in 40000 dwellings in the UK, The authors focused on building characteristics (house type and double glazing) and construction dates. The results showed that these parameters also have a statistically significant effect on indoor radon values (Hunter et al., 2009). Mäkeläinen et al. (2001) studied correlation in the data from 84 houses in Finland and found substructure and the permeability of the soil to be the most influential factors (Mäkeläinen et al., 2001).

Due to scarce airborne measurements being available, the radon risk prediction approach in Norway relies on the indoor radon measurements in producing a national radon hazard map. Watson et al. (2017) established a new national dataset on indoor radon and investigated the connection between geology and indoor radon values in Norway. Among other things, the authors concluded that due to local variations of certain rock types, established relationships between geology and indoor radon might not be valid in all parts of the country (Watson et al., 2017). An example from France by Ielsch et al. (2010) presents the mapping of GRP in the Bourgogne region (France) by using the approach that classifies geological units according to their uranium content which is determined through the analysis of rock samples. Maps are further developed by adding other parameters and are intended to serve as an operational tool. This methodology is to be used to develop a national map, while the region of Bourgogne was used to present the first application. The authors mention that the map resulted in the identification of new RPA, which will help improve the current limits of the priority areas that are defined by regulations but were based only on administrative borders (Ielsch et al., 2010). Szabó et al. (2014) conducted GRP mapping for the area of central Hungary by using soil gas radon and permeability measurements. The authors used spatial analysis to research the relationship between the aforementioned variables and geological formations. The results showed that 
mountains and hills have the highest soil gas radon concentrations, compared to plains (Szabó et al., 2014). Minda et al. (2009) researched the correlation between indoor radon concentrations and geological formations in Hungary and found stronger correlations in one floor, no-basement houses.

\section{Radon investigation and mapping in Croatia}

Croatian initiatives in the field of radon risk analyses are mostly related to the investigations of indoor radon concentrations and identification of radon prone areas through one national study and several focused studies (Radolić et al., 2005, 2006, 2014). Radolić et al. (2005) studied the radon concentrations in geothermal water and air in nine spa pools in Croatia and estimated an effective dose received by the personnel and visitors. The results showed an average value of $40.3 \mathrm{Bqm}^{-3}$ and varied from 10.9 to $109 \mathrm{Bqm}^{-3}$, the estimation of an effective dose was within the limits of the values set for the workplace (Radolić et al., 2005). The authors also mention that compared to values reported by authors in other countries, the values found in Croatian spas are far from elevated. In 2006, Radolić et al. conducted a one-year long national survey of indoor radon on randomly selected households in Croatia. The total number of households participating in the study was 782 and they were selected proportionally to the number of habitants in each of the twenty counties. Besides the continuous measurements, participants were also interviewed on their lifestyles and building types and properties. The results showed the arithmetic mean value of $68 \mathrm{Bqm}^{-3}$ and the geometric mean of $50 \mathrm{Bqm}^{-3}$, with the arithmetic mean values for twenty counties ranging from 33 to 198 $\mathrm{Bqm}^{-3}$ (Radolić et al., 2006). The authors also reported that indoor radon concentrations found in Croatia were similar to the values found in the Central and Southern European countries. The national survey from 2006 established the national reference values for Croatia (Radolić et al., 2006), where it was also found that the area of Lika-Senj County had radon levels two or three times higher than the national reference. Based on those results, those areas were further investigated with the focus of identification of radon prone areas in Radolić et al. (2014). For the area, the authors reported the arithmetic mean value of $223 \mathrm{Bqm}^{-3}$ and the geometric mean value of $121.9 \mathrm{Bqm}^{-3}$ with the percentage of dwellings with radon concentrations above $300 \mathrm{Bqm}^{-3}$ being $34.7 \%$ (Radolić et al., 2014). A focused study of radon was done with the aim of radon mapping of the city of Osijek (Croatia) (Radolić et al., 1998). Continuous measurements were performed in houses in the city and public buildings (kindergartens and schools) over the period of two to six months, focusing at gathering data on the indoor radon levels, the soil gas radon levels, and the information on building properties (Radolić et al., 1998).
The authors found a positive correlation between the indoor radon values and soil gas radon values.

Measurements of radon concentrations, as well as measurements of total gamma radiation, were conducted for the location in Kaštel Gomilica in order to determine the background radiation of the area (Lovrencic, et al., 2007). The results showed that radon concentrations were highly influenced by physical conditions like wind and pressure, while for gamma radiation, the influence of basement type and effect of disposed TENORM was most important (Lovrencic, et al., 2007).

Vaupotič et al. (2007) studied both the Slovenian and Croatian karstic region, testing soil samples for radon activity concentrations at four locations (three of which are in Croatia). While radon soil gas concentration values varied across the sites, all the samples were found to be unaffected by the local thermal power plant running on coal (Vaupotič et al., 2007).

The Croatian State Office for Radiological and Nuclear Safety (DZRNS) is responsible for conducting an ongoing monitoring of ionizing radiation in the environment. The results of radon concentration measurements in public and residential spaces for 2012 and 2013 are available online in map format at http://radon.dzrns.hr/. The purpose of these investigations was to determine the existing situation to be used as a basis for the preparation of the national radon action plan in accordance with Article 103 of the Directive 2013/59/EURATOM (DZRNS, 2016).

\section{Indoor radon mapping in Croatia and its connection to geology - first step to a geogenic radon map}

The national survey of indoor radon from 2006 by Radolić et al. is the most extensive radon measurement study conducted in Croatia. Most often, indoor radon originates from the ground on which the building was built on or rarely from the building materials or it enters the house through the water supply and is released during the water use (IAEA, 2012). The highest concentrations are usually related to the basements and rooms in the contact with the ground. The major access routes such are gaps in the floors and walls, cavities and cracks in the floors or around the piping, construction joints, etc. (IAEA, 2012).

Figure 3 shows how radon usually enters a building, through 1) cracks in walls; 2) openings in walls and floors; 3) windows positioned near the ground; 4) water and waterworks (water pipes); 5) ground.

Work from Radolić et al. (2006) identified counties in Croatia with elevated indoor radon levels. This data provided the first input for connecting radon levels in Croatia with geological parameters. The County with the highest detected indoor radon level was Lika-Senj County (X), two other Counties with elevated levels are 
Karlovac County (V) and Primorje-Gorski kotar County (IX) (Radolić et al., 2006). Based on the data listed in their work, a map shown in Figure $\mathbf{4}$ was produced, outlining the Counties with the elevated radon levels according to the national survey.

The map shown in Figure 4 was made with two sets of data. The first dataset is related to a table set with el-

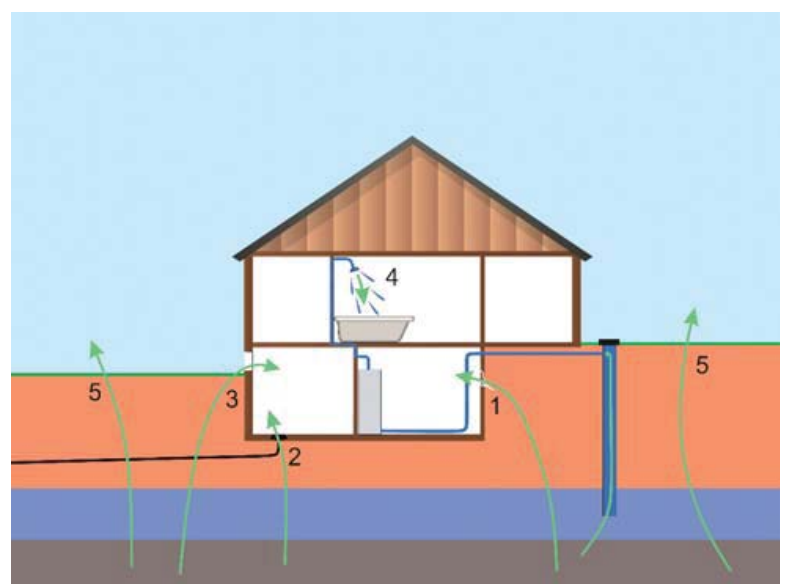

Figure 3: Radon access routes evated indoor radon levels in Croatian Counties (Radolić et al., 2006). This data was transferred to the spreadsheet calculator and supplemented by county numbers in a new field, County ID. The second set of data is the GIS layer which illustrates the spatial extent of Croatian Counties. Those two sets are linked together with the primary key in spreadsheet table and also in a layer's attribute table. The final GIS layer symbology, elevated indoor radon levels were drawn as quantities classified in four classes. Counties with the concentration of indoor radon levels above $100 \mathrm{~Bq} / \mathrm{m}^{3}$ are highlighted here.

The map shown in Figure 5 was made with three sets of data. The first data set is the line GIS layer representing tectonic zones. Tectonic zones are illustrated by important faults and overthrusts which are delineated by geological observations. The second set of data is the GIS layer representing geological deposits, differentiated lithologically and chronostratigraphically. Those two datasets are illustrated on the Geological map of Croatia (Velić, 2007 with references). The third set of data is the GIS layer representing outlined deposits of granites and gneisses, as areas with potentially high radon concentrations.

The map shown in Figure $\mathbf{6}$ is the final map, obtained by a map overlay of the two previous maps. As a result,

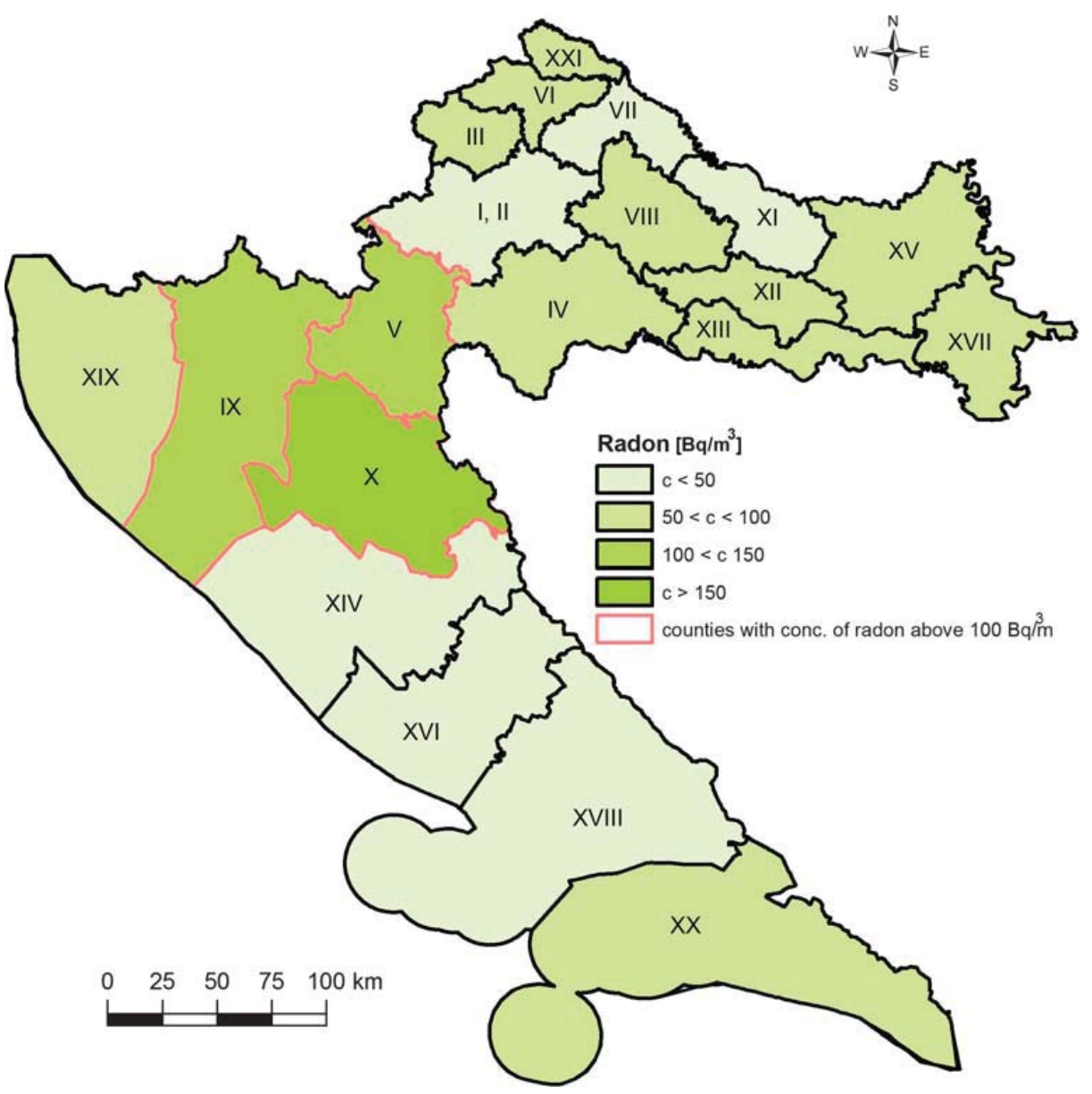

Figure 4: Croatian Counties with elevated indoor radon levels (after Radolić et al., 2006) 


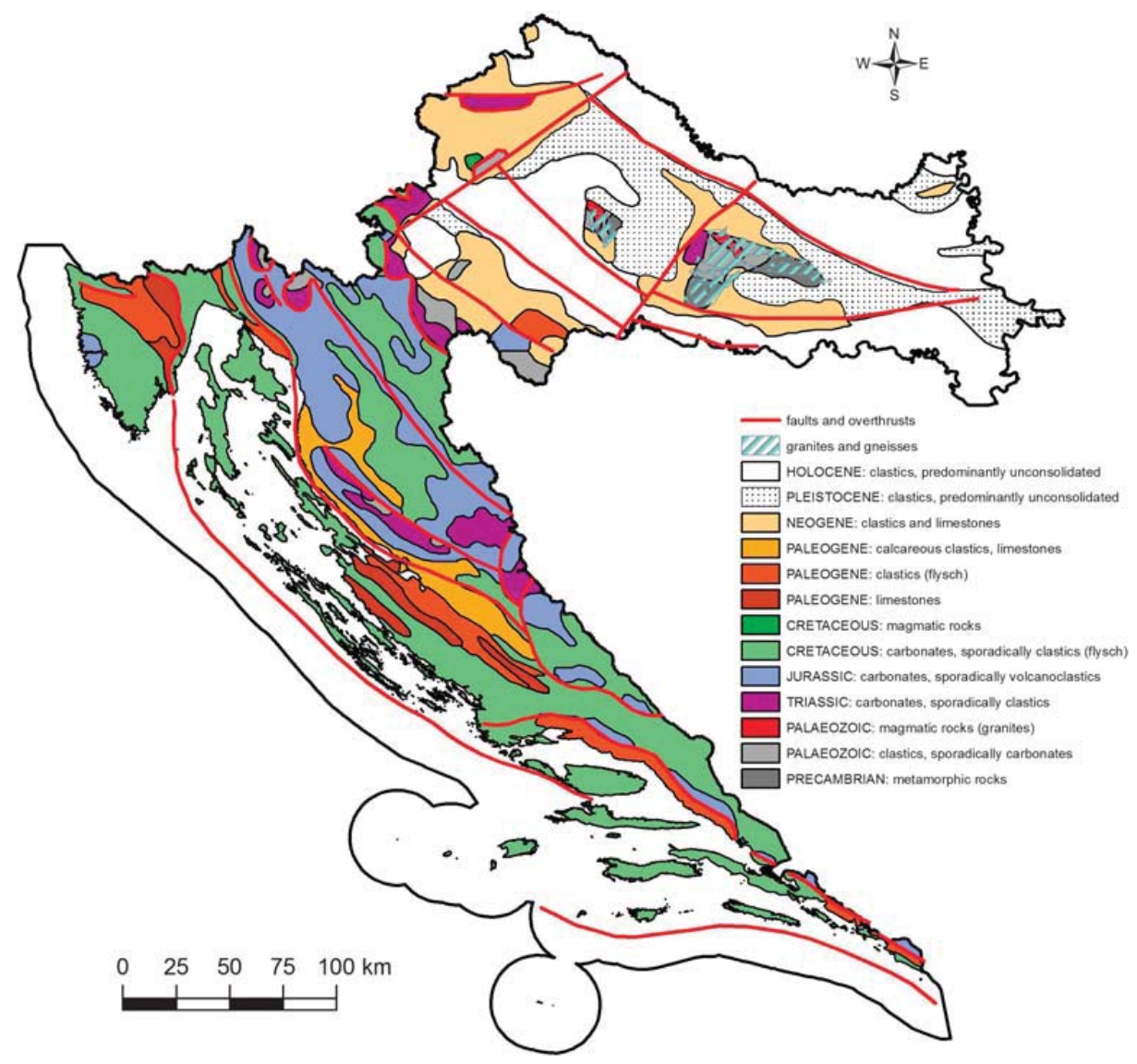

Figure 5: Geological map of Croatia (modified after Velić, 2007 and references therein)

two groups of counties are highlighted. Identified radon prone areas with potential for further research are characterized by elevated radon values in respect to recent fault activity in the Kvarner area and lithological bedrock characteristics (granites and gneisses) in the area of Slavonian mountains (Prelogović et al., 1995; Jurković, 2003; Crnički and Šinkovec, 1993).

\section{Conclusions}

The importance of mapping of different radon phenomenon can be summarized by the role it has in the radiation protection of humans and the environment, on the public, regulatory, and scientific levels. Knowing that radon is the main contributor to the natural background radiation exposure, there is a clear and practical need for the identification of radon prone areas and the monitoring of the radon phenomenon.

A short overview of the European Atlas of Natural Radiation (EANR) project and the continuous work on developing the European Indoor Radon Map (EIRM) and the European Geogenic Radon Map (EGRM) shows the importance of the task in the interdisciplinary and international European context. The practical experiences in the mapping of different aspects of radon (in- door and geogenic) presented herein aspire to illustrate both the importance and the complexity of the work required, as well as the potential that radon mapping has in improving the implementation of radiation protection.

Additionally, this paper presents the mapping of indoor and geogenic radon and how visualization of the mapped data affects interpretation and information dissemination. The main advantages of the GIS system use are evident in improved data visualization and interpretation, linking the geographic and attribute data, and the possibility of interdisciplinary decision-making in the area of different environmental issues.

The existing work related to radon mapping in Croatia consists of the investigations of indoor radon concentrations and identification of radon prone areas through one national study and several focused studies. A simplified correlation between the indoor radon levels and the geological and tectonic parameters presented in Figure 6 identified new potential radon prone areas. This data could be used as input for further research. Since the map relies on the data provided by Radolić et al. (2006), future activities should focus on more extensive research targeting these areas. This new research should be conducted in cooperation with Radolić et al. and could be taken as the first step towards a geogenic map 


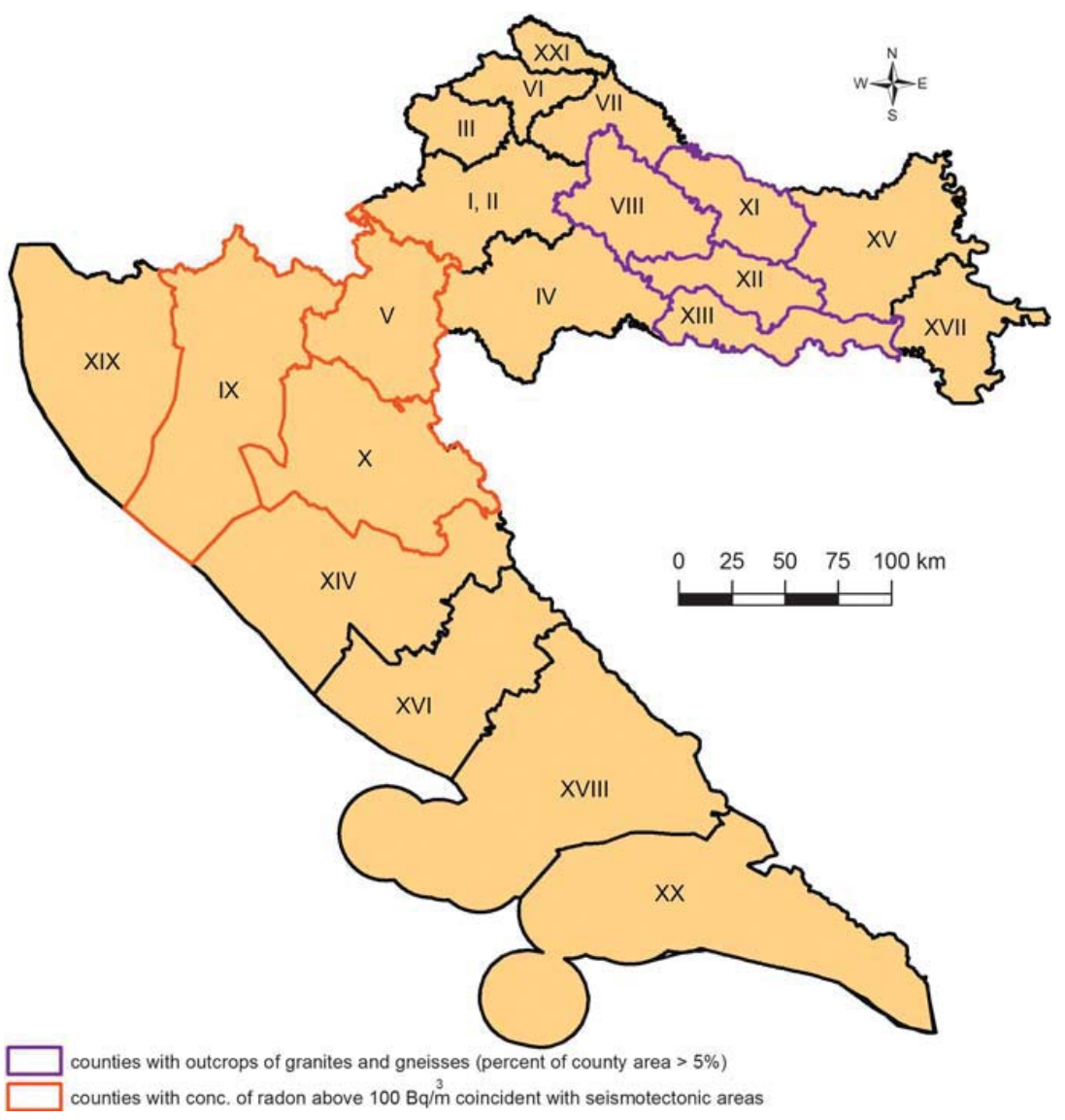

Figure 6: Identified radon prone areas with potential for further research

of radon potential in Croatia. The output of this future research could improve the ability of different users to access information and also contribute to key international initiatives in this field.

\section{References}

Bossew, P., Dubois, G. \& Tollefsen, T. (2008): Investigations on indoor Radon in Austria, part 2: Geological classes as categorical external drift for spatial modelling of the Radon potential. Journal of Environmental Radioactivity, 99, 1, 81-97.

Chambers, D.B. and Zielinski, J.M. (2011): Residential Radon Levels around the World. Encyclopedia of Environmental Health, 828-839. Available at: http://www.sciencedirect. com/science/article/pii/B9780444522726000970

Cinelli, G. and Tollefsen, T. (2016): Radon Mapping in the European Atlas of Natural Radiation. 1(May), 23-27.

Ciotoli, G., Voltaggio, M., Tuccimei, P., Soligo, M., Pasculli, A., Beaubien, S.E. \& Bigi, S. (2017): Geographically weighted regression and geostatistical techniques to construct the geogenic radon potential map of the Lazio region: A methodological proposal for the European Atlas of Natural Radiation. Journal of Environmental Radioactivity, 166, 355-375. http://dx.doi.org/10.1016/j.jenvrad.2016. 05.010
Crnički, J. and Šinkovec, B. (1993): Nemetalne mineralne sirovine Hrvatske. (Non-metallic mineral resources of Croatia) Rudarsko-geološko-naftni zbornik, 5, 1, 21-37. Available at: http://hrcak.srce.hr/13722 (in Croatian)

De Cort, M., Gruber, V., Tollefsen, T., Bossew, P. \& Janssens, A. (2011): Towards a European Atlas of natural radiation: goal, status and future perspectives. Radioprotection, 46, 6, S737-S743.

Dubois, G. (2005): An overview of radon surveys in Europe. ReportEUR21892EN. Office for Official Publications of the European Communities, Luxembourg, 168.

Dubois, G., Bossew, P., Tollefsen, T. \& De Cort, M. (2010): First steps towards a European atlas of natural radiation: Status of the European indoor radon map. Journal of Environmental Radioactivity, 101, 10, 786-798. http://dx.doi. org/10.1016/j.jenvrad.2010.03.007

DZRNS (Državni zavod za radiološku i nuklearnu sigurnost) (State Office for Radiological and Nuclear Safety). (2016): Izvješće o zaštiti od ionizirajućeg zračenja i nuklearnoj sigurnosti za razdoblje 2014.-2015. (Report on ionizing radiation protection and nuclear safety for period 2014-2015), Zagreb: DZRNS, 89. Available at: http://cms.dzrns.hr/images/50001096/Izvjesce\%20o\%20zastiti\%20od\%20ionizirajuceg\%20zracenja\%20i\%20nuklearnoj\%20sigurnosti\%20za\%20razdoblje\%202014.-2015.\%20DZRNS.pdf 
EC (European Commission). (2013): Council Directive 2013/ 59/Euratom of 5 December 2013 Laying down Basic Safety Standards for Protection against the Dangers Arising from Exposure to Ionising Radiation. Official Journal L13 of 17/ 01/2014 European Commission, Bruxelles.

Etiope, G. and Martinelli, G. (2002): Migration of carrier and trace gases in the geosphere: An overview. Physics of the Earth and Planetary Interiors, 129, 3-4) 185-204. https:// doi.org/10.1016/S0031-9201(01)00292-8

Friedmann, H., Baumgartner, A., Bernreiter, M., Gräser, J., Gruber, V., Kabrt, F., Kaineder, H., Maringer, F.J., Ringer, W., Seidel, C. \& Wurm, G. (2017): Indoor radon, geogenic radon surrogates and geology - Investigations on their correlation. Journal of Environmental Radioactivity, 166, 382-389. https://doi.org/10.1016/j.jenvrad.2016.04.028

García-Talavera, M., García-Pérez, A., Rey, C. \& Ramos, L. (2013): Mapping radon-prone areas using $\gamma$-radiation dose rate and geological information. Journal of Radiological Protection, 33, 3,.605. Available at: http://iopscience.iop. org/0952-4746/33/3/605\%5Cnhttp://iopscience.iop.org/ 0952-4746/33/3/605/\%5Cnhttp://iopscience.iop.org/09524746/33/3/605/pdf/0952-4746_33_3_605.pdf

Gregorič, A., Zmazek, B., Džeroski, S., Torkar D \& Vaupotič, J. (2012): Radon as an Earthquake Precursor - Methods for Detecting Anomalies. In: D'Amico, S. ed. Earthquake Research and Analysis - Statistical Studies, Observations and Planning. InTech, 179-196.

Gruber, V., Bossew, P., De Cort, M. \& Tollefsen, T. (2013): The European map of the geogenic radon potential. Journal of radiological protection: official journal of the Society for Radiological Protection, 33, 1, 51-60. Available at: http://www.ncbi.nlm.nih.gov/pubmed/23295644

Hunter, N., Muirhead, C.R., Miles, J.C.H. \& Appleton, J.D. (2009): Uncertainties in radon related to house-specific factors and proximity to geological boundaries in England. Radiation Protection Dosimetry, 136, 1, 17-22. https://doi. org/10.1093/rpd/ncp148

IAEA (International Atomic Energy Agency). (2012): Protection of the Public against Exposure Indoors due to Natural Sources of Radiation., p.112. Available at: http://wwwpub.iaea.org/MTCD/Publications/PDF/Pub1651Web-624 73672.pdf

ICRP (International Commission on Radiological Protection). (1987): Lung Cancer Risk from Exposures to Radon Daughters. ICRP Publication 50. Ann. ICRP 17, 1.

ICRP (International Commission on Radiological Protection). (2010): Lung Cancer Risk from Radon and Progeny and Statement on Radon. ICRP Publication 115, Ann. ICRP 40, 1.

Ielsch, G., Cushing, M.E., Combes, P. \& Cuney, M. (2010): Mapping of the geogenic radon potential in France to improve radon risk management: Methodology and first application to region Bourgogne. Journal of Environmental Radioactivity, 101, 10, 813-820. http://dx.doi.org/10.1016/ j.jenvrad.2010.04.006

Jurković, I. (2003): Metalogenija južne Tisije - Moslavačka Gora, Psunj, Papuk, Krndija. (Metallogenesis of South Tisia - Moslavačka Mt., Psunj, Papuk, Krndija Mts.) Ru- darsko-geološko-naftni zbornik, 15, 1, 1-17. Available at: http://hrcak.srce.hr/13380 (in Croatian)

Kemski, J., Siehl, A., Stegemann, R. \& Valdivia-Manchego, M. (2001): Mapping the geogenic radon potential in Germany. Science of the Total Environment, 272, 1-3, 217230. https://doi.org/10.1016/S0048-9697(01)00696-9

Kemski, J., Klingel, R., Siehl, A. \& Valdivia-Manchego, M. (2009): From radon hazard to risk prediction-based on geological maps, soil gas and indoor measurements in Germany. Environmental Geology, 56, 7, 1269-1279. https:// doi.org/10.1007/s00254-008-1226-Z

Lovrencic, I., Barisic, D., Orescanin, V. \& Lulic, S. (2007): In situ determination of radon concentration and total gamma radiation in Kastel Gomilica, Croatia. Nuclear Instruments and Methods in Physics Research, Section B: Beam Interactions with Materials and Atoms, 263, 1 SPEC. ISS., 186-190. https://doi.org/10.1016/j.nimb.2007.04.084

Minda, M., Toth, G., Horvath, I., Barnet, I., Hamori, K. \& Toth, E. (2009): Indoor radon mapping and its relation to geology in Hungary. Environmental Geology, 57, 3, 601609. https://doi.org/10.1007/s00254-008-1329-6

Neznal, M., Neznal, M., Matolin, M., Barnet, I., \& Miksova, J. (2004): The New Method for Assessing the Radon Risk of Building Sites. Czech Geol. Survey Special Pa- pers, 16. Czech Geol. Survey, Prague, 7-13. Available at: http:// www.radon-vos.cz/pdf/metodika.pdf

Prelogović, E., Kuk, V., Jamičić, D., Aljinović, B., Marić, K. (1995): Seizmotektonska aktivnost Kvarnerskog područja (Seismotectonic activity of the Kvarner region). 1. Hrvatski geološki kongres (First Croatian geological congress), Vlahović, Igor, Ivo Velić \& Marko Šparica (Ed.). Zagreb: Institut za geološka istraživanja, 487-490. (in Croatian)

Radolić, V., Faj, Z., Šmit, G., Čulo, D., \& Planinić, J. (1998): Radonski zemljovid za grad Osijek (Radon mapping of the Osijek town). Zbornik radova četvrtog simpozija Hrvatskog društva za zaštitu od zračenja, Obelić, B. \& Franić, Z. (Ed.). Zagreb: HDZZ, 343-348. (in Croatian)

Radolić, V., Vuković, B., Šmit, G., Stanić, D. \& Planinić, J. (2005): Radon in the spas of Croatia. Journal of Environmental Radioactivity, 83, 2, 191-198. https://doi.org/ 10.1016/j.jenvrad.2005.02.016

Radolić, V., Vuković, B., Stanić, D., Katić, M., Faj, Z., Šuveljak, B., Lukačević, I., Faj, D., Lukić, M. \& Planinić, J. (2006): National survey of indoor radon levels in Croatia. Journal of Radioanalytical and Nuclear Chemistry, 269, 1, 87-90. https://doi.org/10.1007/s10967-006-0234-2

Radolić, V., Miklavčić, I., Stanić, D., Poje, M., Krpan, I., Mužević, M., Petrinec, B. \& Vuković, B. (2014): Identification and mapping of radon-prone areas in Croatia-preliminary results for Lika-Senj and the southern part of Karlovac counties. Radiation Protection Dosimetry, 162, 1-2, 29-33. https://doi.org/10.1093/rpd/ncu212

Sainz Fernández, C., Quindós Poncela, L.S., Fernández Villar, A., Fuente Merino, I., Gutierrez-Villanueva, J.L., Celaya González, S., Quindós López, L., Quindós López, J., Fernández, E., Remondo Tejerina, J., Martín Matarranz, J.L. \& García Talavera, M. (2017): Spanish experience on the design of radon surveys based on the use of geogenic 
information. Journal of Environmental Radioactivity, 166, 2016, 390-397. http://dx.doi.org/10.1016/j.jenvrad.2016. 07.007

Sykora, I. (2010): Radionuclides as Tracers of Atmospheric Processes. In: Froehlich, K. ed. Environmental radionuclides: tracers and timers of terrestrial processes, Radioactivity in the environment. Elsevier B.V., 51 -84.

Szabó, K.Z., Jordan, G., Horváth, Á. \& Szabó, C. (2014): Mapping the geogenic radon potential: Methodology and spatial analysis for central Hungary. Journal of Environmental Radioactivity, 129, 107-120. http://dx.doi.org/10. 1016/j.jenvrad.2013.12.009

Tollefsen, T., Cinelli, G., Bossew, P., Gruber, V. \& De Cort, M. (2014): From the European indoor radon map towards an atlas of natural radiation. Radiation Protection Dosimetry, 162, 1-2, 129-134. Available at: https://academic.oup. com/rpd/article-lookup/doi/10.1093/rpd/ncu244

Tracy, L. Bliss. (2010): Radon. In: Atwood., D. A. Radionuclides in the Environment. Wiley, 191-206.

UNSCEAR (United Nations Scientific Committee on the Effects of Atomic Radiation), (2000): Annex B. Exposures from natural radiation sources. UNSCEAR 2000 Report,
1, 74. Available at: http://www.unscear.org/unscear/en/publications/2000_1.html

Vaupotič, J., Barišić, D., Kobal, I. \& Lulić, S. (2007): Radioactivity and Radon potential of the terra rossa soil. Radiation Measurements, 42, 2, 290-297. https://doi.org/10.1016 /j.radmeas.2007.01.034

Velić, I. (2007): An outline of the geology of Croatia. Field Trip guidebook and Abstracts. 9th International Symposium on Fossil Algae. Grgasović T. \& Vlahović, I. (Ed.). Zagreb: Croatian Geological Survey, 5-7.

Wakeford, R. (2004): The cancer epidemiology of radiation. Oncogene, 23, 38, 6404-6428. Available at: http://www. ncbi.nlm.nih.gov/pubmed/15322514\%5Cnhttp://www.nature.com/onc/journal/v23/n38/pdf/1207896a.pdf

Watson, R.J., Smethurst, M.A., Ganerød, G. V., Finne, I. \& Rudjord, A.L., (2017): The use of mapped geology as a predictor of radon potential in Norway. Journal of Environmental Radioactivity, 166, 341-354. http://dx.doi. org/10.1016/j.jenvrad.2016.05.031

WHO (World Health Organization). (2009): Who Handbook on Indoor Radon - A Public Health Perspective. World Health Organization, 110. Available at: http://apps.who. int/iris/bitstream/10665/44149/1/9789241547673_eng.pdf

\section{SAŽETAK}

\section{Kartiranje radona u Hrvatskoj i njegova povezanost s geologijom}

Radon je poznat kao glavni doprinositelj prirodnoj pozadinskoj izloženosti zračenju, a kartiranje različitih fenomena radona važan je zadatak kako u znanstvenome, tako i u regulatornome kontekstu. Uzimajući u obzir utjecaj radona na zdravlje, identifikacija područja s povišenim razinama radona ključan je korak u praćenju stanja (monitoringu) radona te sprječavanju štetnih učinaka na populaciju i okoliš. Različite potrebe vezane uz praćenje razina radioaktivnosti u Europi dovele su do inicijativa poput razvoja Europskoga atlasa prirodnoga zračenja (EANR). Kako bi se predstavile različite metode kartiranja radona, ukratko su opisani projekti Europske karte razine unutarnjega radona i Europske karte geogenoga radona. Cilj je ovoga rada prezentirati kartiranje različitih aspekata radona (unutarnjega i geogenoga) i važnost kartiranja u vizualizaciji podataka i širenju informacija. Praktična iskustva iz svijeta pružaju kontekst za buduće aktivnosti kartiranja radona u Hrvatskoj. Postojeće hrvatske inicijative na području istraživanja radonskoga rizika uglavnom se odnose na istraživanje koncentracija radona u zatvorenome prostoru i identifikaciju područja izloženih radonu kroz jednu nacionalnu studiju i nekoliko fokusiranih studija. Usporedba razina unutarnjega radona u Hrvatskoj i nekoliko geoloških parametara identificirala je nova područja prikladna za buduća istraživanja koja bi vodila prema karti geogenoga potencijala radona u Hrvatskoj.

\section{Ključne riječi:}

kartiranje radona, geologija, Hrvatska, GIS, prirodna radioaktivnost

\section{Authors contribution:}

Ana Mostečak (PhD student) collected and interpreted the materials and wrote the first version of the paper. Želimir Veinović (Assistant Professor) and Dario Perković (Assistant Professor) had the initial idea for the paper topic. Dario Perković performed the work related to the mapping. Frankica Kapor (Full Professor), Dario Perković and Želimir Veinović reviewed and performed critical reading and approved the final version of the manuscript. 